\title{
The Fairy Tales' Stepmothers: They are not Evil, They are just Insecure (Portraying the Character of Cinderella, Hansel and Gretel, and Snow White's Stepmothers from the Appraisal Framework)
}

\author{
Dyah Ayu Nila Khrisna \\ \{dahayu@staff.uns.ac.id\} \\ Universitas Sebelas Maret
}

\begin{abstract}
The wicked stepmother 's character is prevalent in fairy tales. Stepmother reflects qualities that we associate with evil deeds and is always interesting to be examined. Their Characterizations are mostly disclosed with a feminist approach in literature and psychology framework, but rarely seen from a linguistic point of view. This article aimed at portraying the character of stepmothers in the most famous fairy tale Cinderella, Hansel and Gretel, and Snow White and investigating the characterization from a different standpoint. The application of the Appraisal theory yields a new finding revealing the insecurity of the stepmothers despite their iniquity. This analysis also concerns the translation equivalence. The results of the assessment demonstrate the translator's quality in portraying nearly the same personality of the stepmothers in the original version.
\end{abstract}

Keywords: Stepmothers, Fairy tales, Characterization, Appraisal, Translation

\section{Introduction}

In fairy-tale terms, the stepmother represents qualities that we equate with evil: rage, envy, resentment, greed, self-absorption, clever inventiveness, and supernatural powers. Stepdaughters are the most popular victim of her marriage. Seldom do we meet compassionate stepmother, for, like all fairy tale figures, this step-mother is an archetypal image, not the representation of a true person whose values, desires, and thoughts we are deprived of. The evil stepmother includes all that we fear and despise for the feminine, the female creature whose hideous nature and cruelty frighten us. Her capacity to bewitch and the endless amount of energy she uses to bring out her filthy impulses is a matter of nightmares. She is also put up as a foil to the naive and innocent step girl whom she mistreats and who eventually gains victory over her.

The character of the wicked stepmother is popular in fairy tales; the most common examples are Cinderella, Snow White, and Hansel and Gretel. The characterization of the stepmother is without a doubt always enthralling to scrutinize. Many scholars had investigated this distinctive character from myriad viewpoints. From a feminist perspective, for instance, Blair (2015) queried on the choice of old and female figures for the antagonist [1]. Some also concern on tale exemplifying that women should be mothers or wives. Nanda (2014) stated that "Much of the fairy tale literature reinforces the idea that women should be wives and mothers, 
submissive and self-sacrificing." [2] Reba (2015) endeavors to discover the pervasive portrayal of antagonistic women within fairy tale literature and argue that evil women in fairy tales are not only used to destroy the important bonds between older women and younger women but also to reinforce the stereotypically feminine qualities sought in women." [3]

Characterization is also commonly disclosed with literature and psychology approach but rarely seen from a linguistic point of view. Khrisna (2016) had conducted a study on the characterization of Santiago in the novel The Old Man and The Sea and succeeded to divulge the profound emotion of this character [4]. The use of Appraisal theory from Systemic Functional Linguistic Study revealed the frequent occurrence of Affect in each stage of the story which strongly proves that the character of Santiago is described more on his emotion than his personality. Appraisal simply means evaluating something like individuals, objects, situations, etc. The appraisal was developed in 2003 by Martin and Rose and was improved in 2005 by Martin and White. Martin and Rose (2005) define Appraisal as "evaluation of kinds attitudes that are negotiated in the texts, how strong are the feelings that are involved, and how the values are sourced to the readers."[5]

Considering its efficaciousness, this research is trying to apply the same theory to disclose the other side of stepmothers' personality which is universally perceived as wicked and evil. Garber (2015) had noticed the change of nuance of the stepmother characterization in Cinderella movie released in 2015; from wicked to cruel. She found an interesting fact that "Lady Tremaine's abuse of Cinderella is not the result, her performance makes clear, of some sui generis malevolence; it is instead the direct result of the cruelties her own life has heaped upon her." [6] This finding is without a doubt worth further investigation

\section{Research Methodology}

The review of this paper focuses primarily on the personality, normality, and physical look of the stepmothers depicted in WOW! bilingual English-Indonesian comics of Cinderella, Hansel and Gretel, and Snow White [7] [8] [9]. The analysis covers three main elements comprising Affect, Judgment, and Appreciation, which can systematically view the interpretation of stepmothers from a broader perspective. The Affect factor plays a role in deciding their emotions. Judgment is the role of disclosing their actions, and Appreciation is to assess their appearance. Besides, this work also examines the equivalence of the messages between the English and Indonesian versions.

All narrations and utterances containing language evaluation conveyed by and directed to the stepmothers were described as the primary data and were collected using a content analysis technique. The data were subsequently classified into tables-based categories of the Appraisal theory and interpreted based on the context of the situation, pictures, related studies, and other supporting data. Subsequently, an assessment was carried out on the quality of the translation. The translation is equal in meaning if the classified Appraisal elements are almost similar to those found in the original. 


\section{Results}

\subsection{The Portrayal of Cinderella's Stepmother}

The result shows that Cinderella's step mother is not accentuated by her outward appearance. No linguistic data have been found to provide the physical characteristics of the stepmother. Despite the discovery of some facets of the negative appraisal of Judgement, the evil characters are still very obvious, in particular the type of propriety: ethics, which give an appraisal on the morality aspect. The language evaluation appears in the following picture:

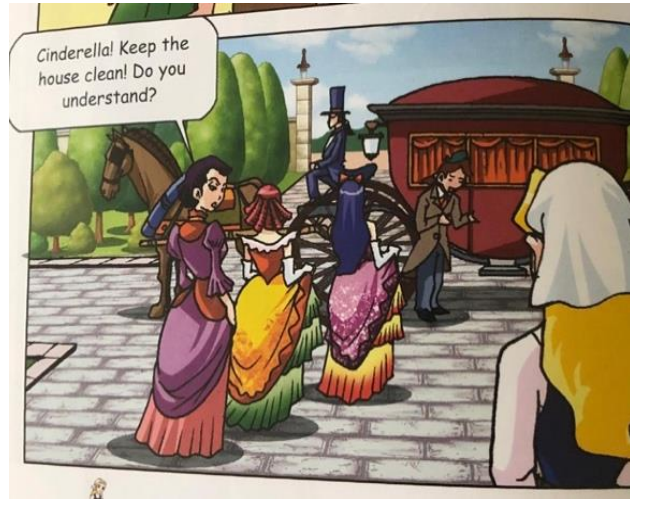

Fig. 1. The scene evaluating Judgement (Cinderella English version)

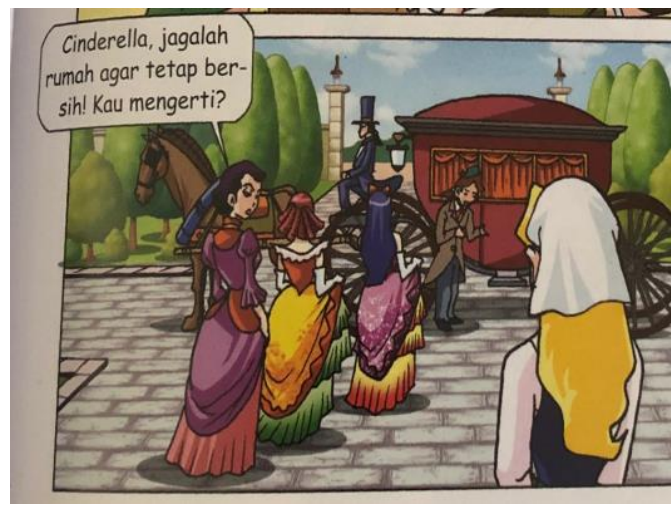

Fig. 2. The scene evaluating Judgement (Cinderella Indonesian version)

Figure 1. shows the situation when the stepmother and the two step-sisters of Cinderella will leave for the palace to meet the invitation to the prince's party. The bad attitude of the Stepmother can be seen from the phrase "Keep the house clean! Do you understand?" This implies the injustice that she addresses to Cinderella, given that the invitation was intended for all, including Cinderella. It also reveals in the scene that this expression presents itself with an eyebrow cocked. Nevertheless, the wrongdoing portrayed in the text and picture cannot be defined as 'wicked' because no lexical signs are suggesting an elevated degree of Graduation in the expression. In this case, the character of the stepmother is more justified in naming herself cruel than wicked or evil. The intensity of cruelty tends to decline in translation. The Indonesian version of the comic-cut does not have the same attitude as the source text. This inequality can be seen from the use of the word "Jagalah" (Take care) which in fact gives a positive connotation to the character of the speaker. It could lead to a wrong interpretation unless the text is presented with the picture.

Interestingly, the bad attitudes of Cinderella's stepmother are not perceived as much as her feelings as evinced in the findings of the Affect aspect which is over the Judgement. It is even only uttered once in the narration, and other characters share only a few. The character of Cinderella's stepmother in this comic is rich with a sense of insecurity instead of cruelty. The story catches the notion that Cinderella is a threat for the step mother, as she believes that Cinderella has greater significance than her two daughters. The feeling of insecurity can be seen in the following example. 


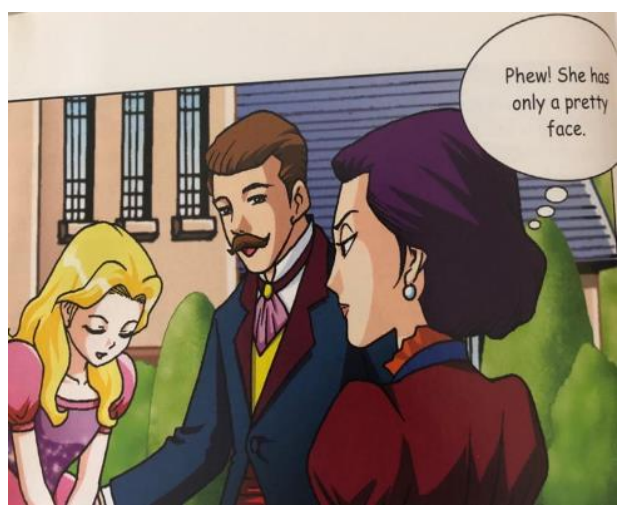

Fig. 3. The scene evaluating Affect (Cinderella English version)

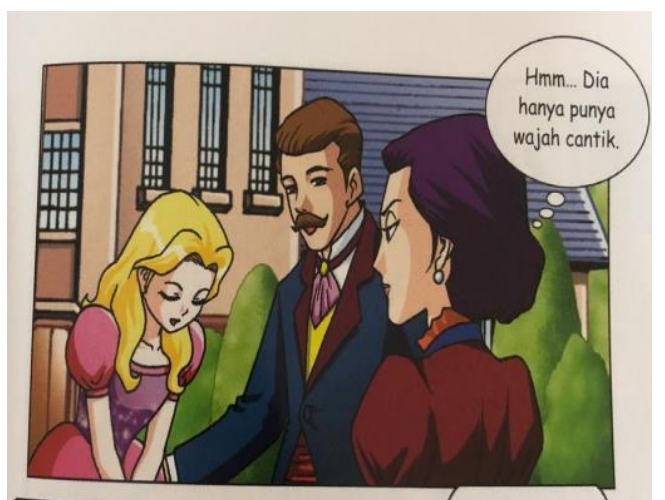

Fig. 4. The scene evaluating Affect (Cinderella Indonesian version)

The 'Phew!' exclamation reveals the stepmother's anxiety as she first noticed that Cinderella has a pretty face, but then it is a relief to see her naivety. It is reflected in the utterance of "She has only a pretty face." The word 'only' is the keyword reinforcing the fusion of the two emotions. The sinister facial expression shown by the stepmother emphasizes the uneasy feeling that she is attempting to communicate. Unfortunately, the Indonesian translation does not convey the same feeling as contained in the source language. Altering "Phew!" into "Hmm..." as seen in the figure 4 causes change in the Attitude evaluation.

In addition, the insecurities of the stepmother over the presence of Cinderella can also be seen in the following figure:

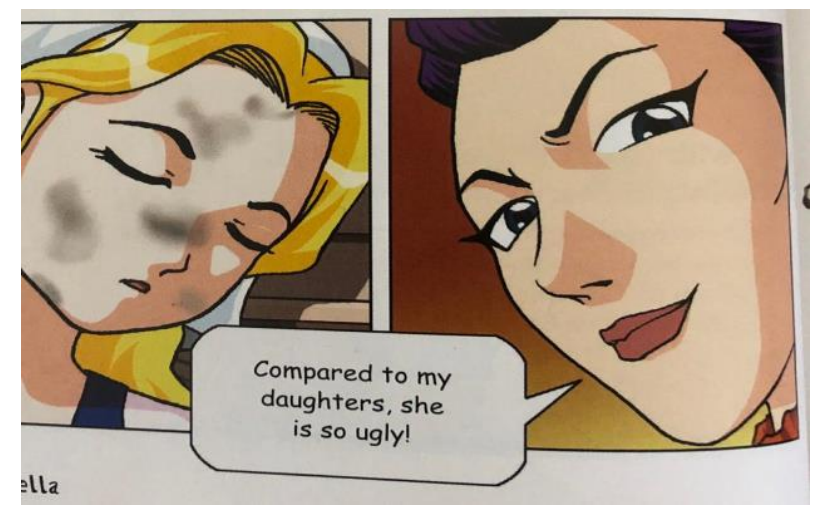

Fig. 5. The Insecurity of Cinderella's Stepmother

Cinderella is a threat to her children. She argues that Cinderella is more attractive than her daughters and hides her fears (insecurity: disquiet) by saying, "Compared to my daughters, she is so ugly!" illustrated with an expression that suggests annoyance. This term often signifies a feeling of love that a mother has for her children. In reality, she is just a mother who wants to 
bring her kids the best. Her bad personality never targets her biological children. This can be shown by the sympathy and encouragement the stepmother gives to her children as seen in the phrase "Of course my beautiful daughters are invited" and "Your sisters are too weak to do those things." Each of these phrases includes an appraisal key aspect of Affect: happiness: affection, which is translated equally into "Tentu saja, putri-putriku yang cantik diundang" and "Kakakmu terlalu lemah untuk mengerjakan pekerjan seperti itu."

This Cinderella comic story-writer seems to have revealed the stepmother's other characteristics; a mother's caring nature. She is portrayed as being very sorry for her mistakes, and she is finally allowed to share her happiness with Cinderella. This is very rare in the Cinderella stories. In this plot, readers could feel very much the guilt of the stepmother, as it is illustrated with visual representations showing her in a kneeling position with tears in her eyes.

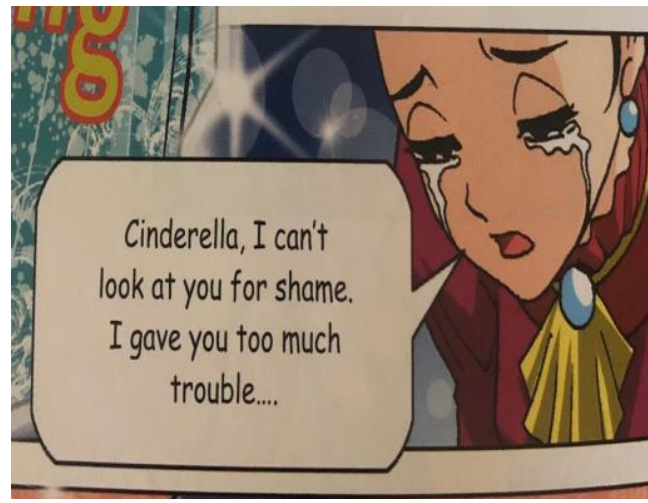

Fig. 6. The Guilt of Cinderella's Stepmother (English Version)

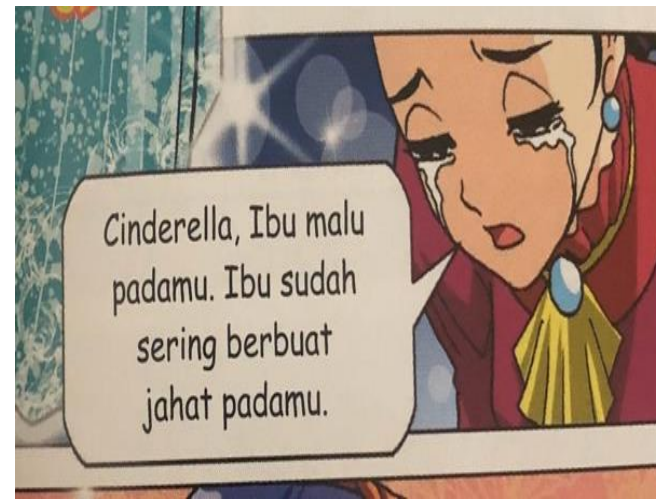

Fig. 7. The Guilt of Cinderella's Stepmother (Indonesian Version)

The Stepmother's conscience is also reflected in the word "shame" which evaluates the element of the Affect and is classified as Unhappiness: misery. It creates a powerful word and elevated degree to reflect the disappointment in Graduation. There is an omission in the Indonesian version of the utterance "I can't look at you," which lowers the depth of remorse that the writer intends to convey in the character of the stepmother.

\subsection{The Portrayal of Hansel and Gretel's Step Mother}

Similar to the characterization of the stepmother in Cinderella comic, the stepmother in the story of Hansel and Gretel is not described in her physical appearance. The evaluation of Appraisal results to the divulgence of insecurities over the cruelty. However, the evil side of the stepmother widely known by society can be still easily recognized through the plot of the story. Below is one of the examples. 


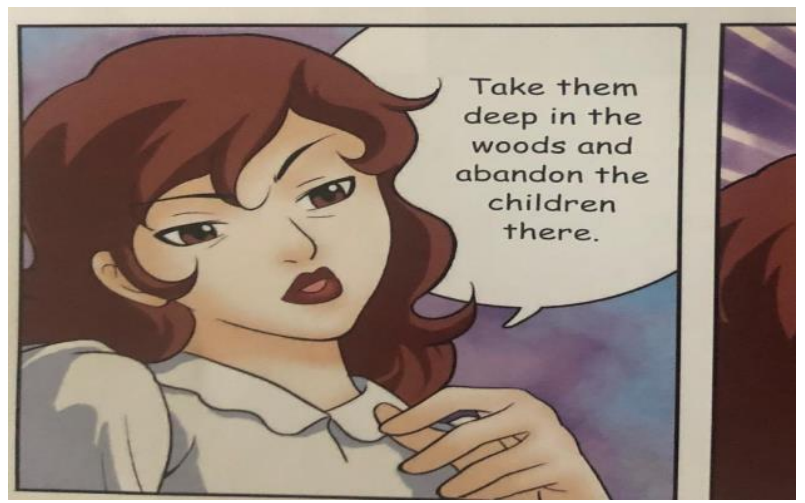

Fig. 8. The Evil Plan of Hansel and Gretel's Stepmother

The plan suggested by the Hansel and Gretel's stepmother in this scene sounds very evil. The keyword of "abandon" says it all. The New Oxford American Dictionary defines this as "leave (a place or vehicle) empty or uninhabited, without intending to return." In the Indonesian version, this word is less equally translated into 'tinggalkan. (leave)'. The word 'tinggalkan' contains a lower expressive meaning than the original. However, the context of the situation and the picture is a perfect combination to bring support to the meaning delivery.

The tenacity of the stepmother in this story is also questionable. The negative judgment on this aspect is found in numerous parts of the story underpinning the bad character. She intimidates and offers difficult choices for her husband, to choose between her and his children, implying her dissolute personality, as seen in the following example.

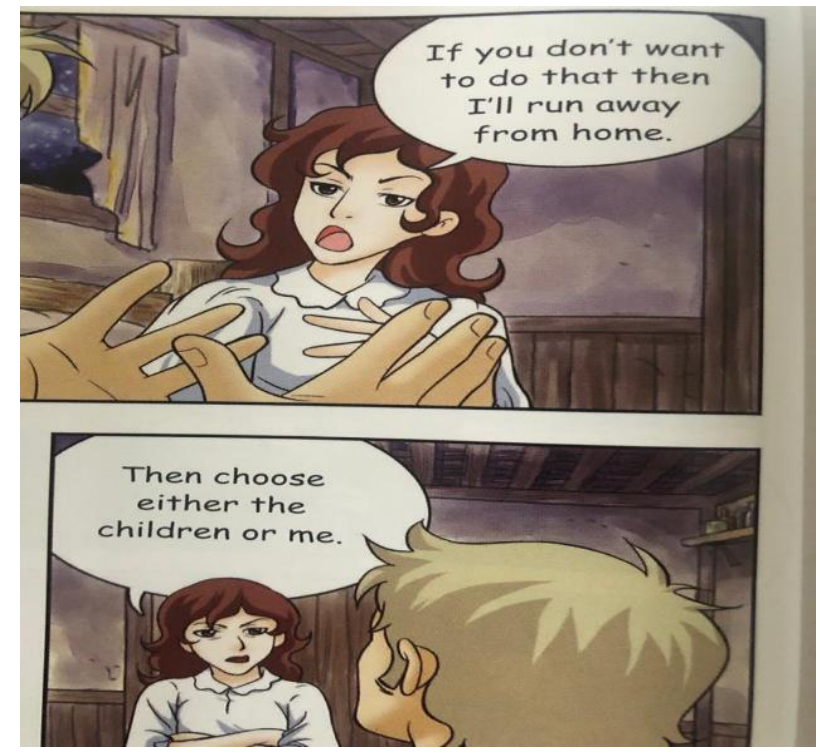

Fig. 9. The Tenacity of Hansel and Gretel's Stepmother 
The gesture she makes while uttering her command to her husband also indicates that she has a dominant personality. Her dominance is not only shown over her husband but also her stepchildren. She frequently utters remarks that are not suitable to express to kids, such as: "You idiot!" "You useless loafers!" when she only means to wake them up from their bedtime as pictured in the following figures.

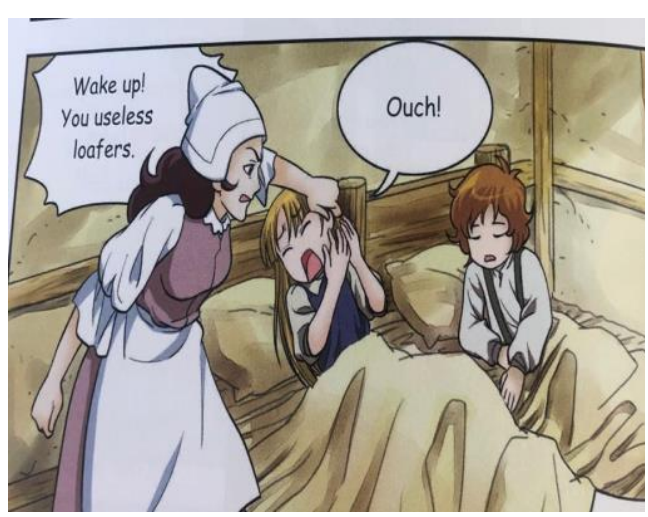

Fig. 10. The Cruelty of Hansel and Gretel's Stepmother (English Version)

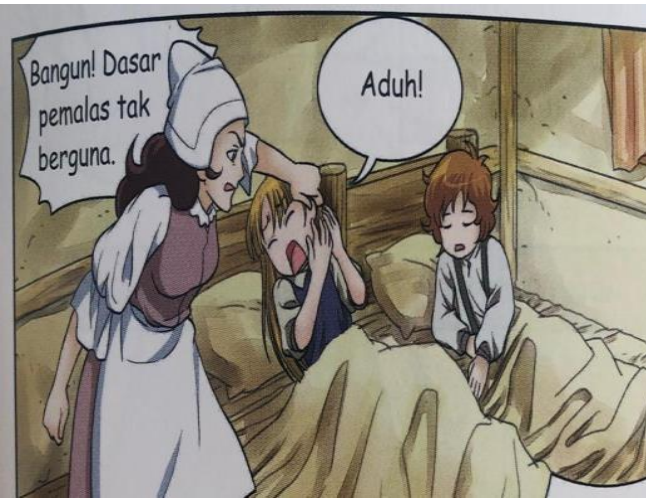

Fig. 11. The Cruelty of Hansel and Gretel's Stepmother (Indonesian Version)

She even tweaks her daughter's ear roughly with the anger showing from her eyes. This particular scene is translated accurately to "Bangun! Dasar pemalas tak berguna." This expression contains strong annoyance of the stepmother at her stepchildren, as strong as the source language.

The explanation behind the step mother's negative attitude towards her children is worthy of further evaluation. The results of this study may be used to describe the true character of the stepmother of Hansel and Gretel. The finding shows that the Affect aspect of Appraisal is acknowledged more than the aspect of Judgement. She was too wrapped in misery. She is, in fact, rich in insecurity due to their poverty. This condition drives her to harm her step-children since her husband fails to fulfill her needs and she fails to develop her sense of belonging for the kids. Her deep sense of insecurity is lucidly narrated at the beginning of the story.

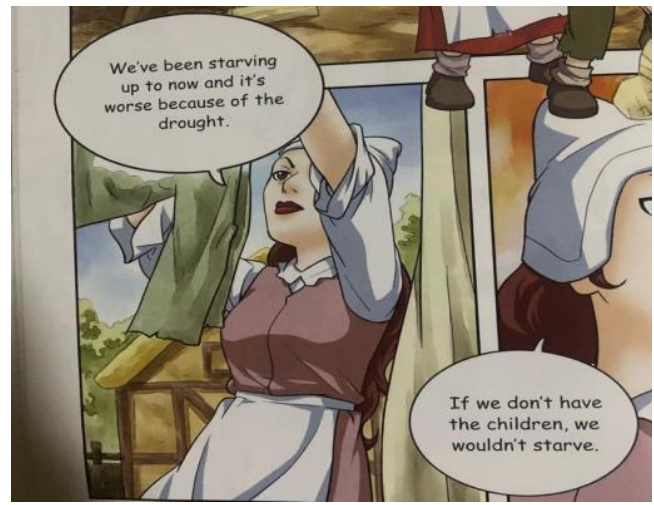

Fig. 12. The Insecurity of Hansel and Gretel's Stepmother (English Version)

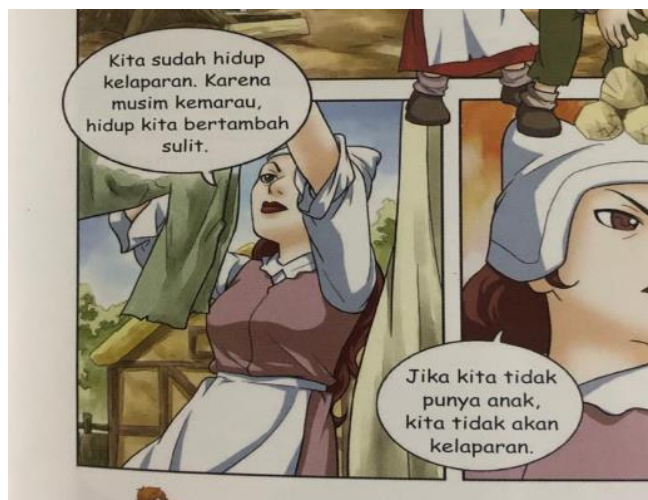

Fig. 13. The Insecurity of Hansel and Gretel's Stepmother (Indonesian Version) 
Starving is the source of her anxiety that prompts her to get rid of her kids. The Indonesian version is successfully conveyed the same feeling of insecurity as seized in the original version as seen in the figure 13. However, there is a slight change in the sentence structure of the translation which also causes a slight change in meaning. The word "starving" is rendered to "Hidup kelaparan" which results in a different object of evaluation. The source language appraises 'starving' but the translation is shifted to 'life'.

\subsection{The Portrayal of Snow White's Step Mother}

Unlike the previous two characterizations of stepmothers, Snow White's stepmother is repeatedly depicted from her physical look, particularly her face. This belongs to her primary concern as well as the source of her wickedness. The Appraisal analysis shows a positive evaluation of the quality aspect of Appreciation which gives value to the beauty of the queen. Her exquisiteness narrates much of the story and she wishes to continues to exist until the end of the story. Even so, her beauty is not the issue that concerns the author, but her personality and her emotion. She is depicted to have erred in both deed and manner from the very beginning she is introduced in the story, as illustrated in the following figures.

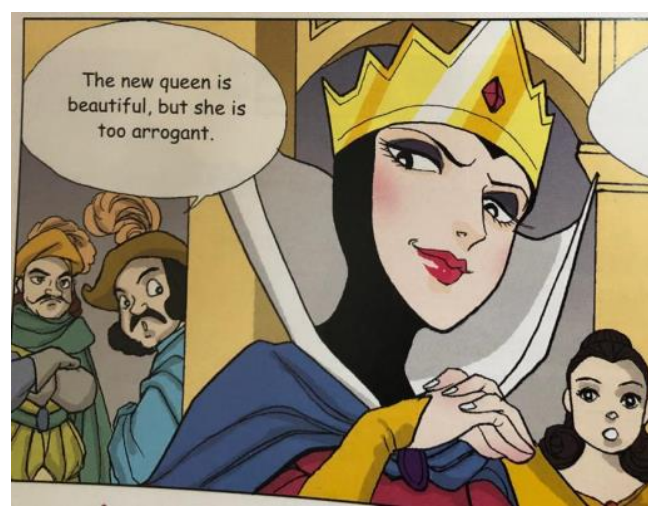

Fig. 14. The Look of Snow White's Step Mother (English Version)

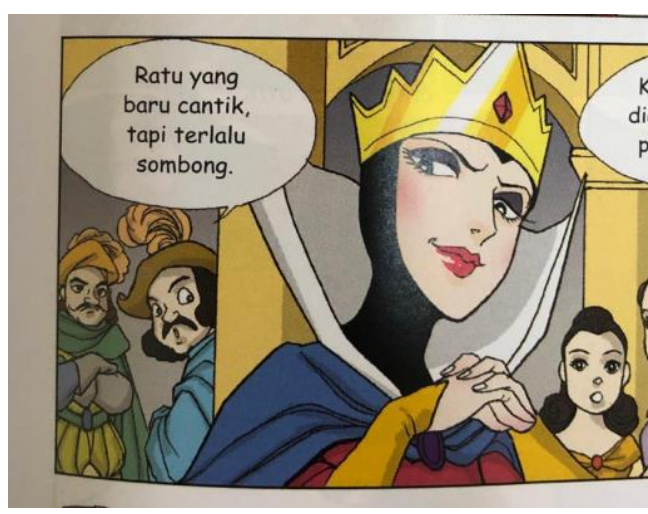

Fig. 15. The Look of Snow White's Step Mother (Indonesian Version)

The beauty of Snow White's stepmother is represented in a glamorous bold makeup look that catches everybody's attention, but sadly in a bad way. People around her cannot deny her beauty but find it hard to accept her personality. They condemn her for being too arrogant and jealous of her stepdaughter. Their hostility can be seen from the facial expressions they make for the queen. The phrase "too arrogant" negatively evaluates the aspect of Judgement, specifically Propriety: ethic, which is equally translated into "terlalu sombong". Also, she is portrayed in her jealousy, which is somewhat different from her depiction in the Indonesian version. The translation of "dia orangnya pendengki" contains a different degree of expressive meaning than "jealous" in the original version. According to the Great Indonesian Dictionary (KBBI), 'pendengki' is equivalent to the term 'envy' and is more complex than just 'jealous.' However, 'pendengki' is not appropriate as an adjective to the Indonesian sentence form. It is generally used as a noun. The stepmother of Snow White used to be described as the most beautiful woman as illustrated in the following figure. 


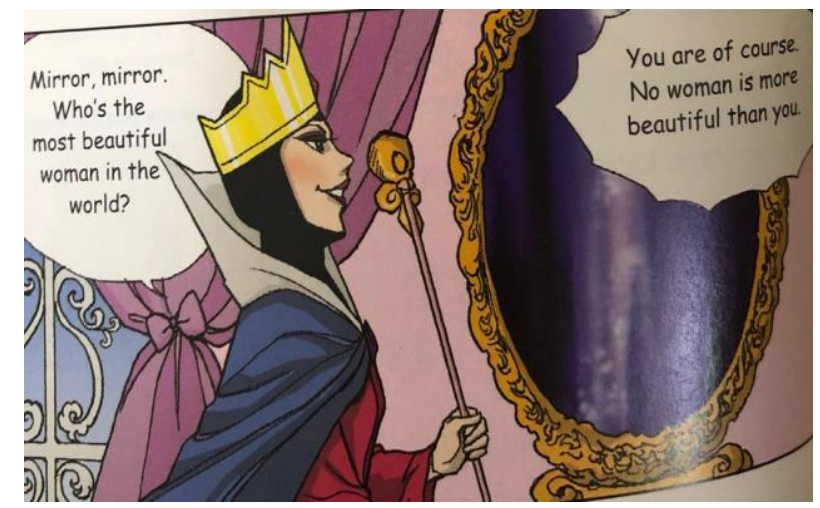

Fig. 16. The scene evaluating Appreciation

The only thing she can trust is the mirror. She would accept all its statements as true. It says that the queen was the most beautiful woman in the world and that no one was more beautiful than her. It has always been her joy before the arrival of Snow White. Yes, she is her stepdaughter, who is now growing up to be a beautiful young lady, which is triggering her anxiety. The following expressions made it obvious that she is insecure. She confesses that she is nervous to see Snow White grows prettier day by day. This emotional response is properly translated into "cemas" in Indonesian. The feeling of insecurity is profound in the storyline which triggers her to do evil things.

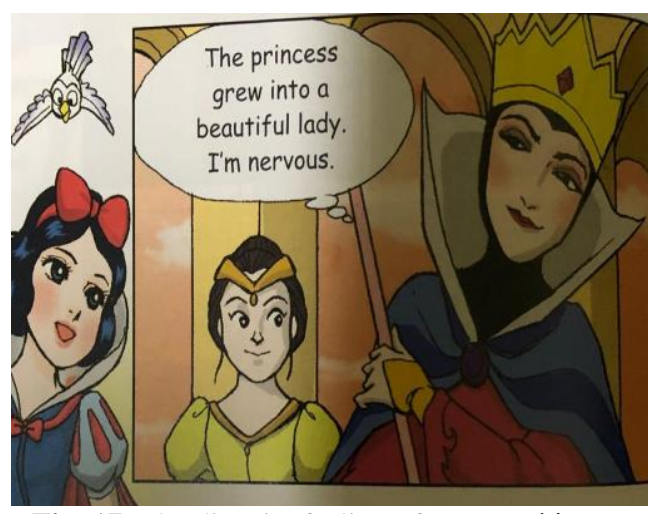

Fig. 17. The disquiet feeling of Snow White's stepmother (English Version)

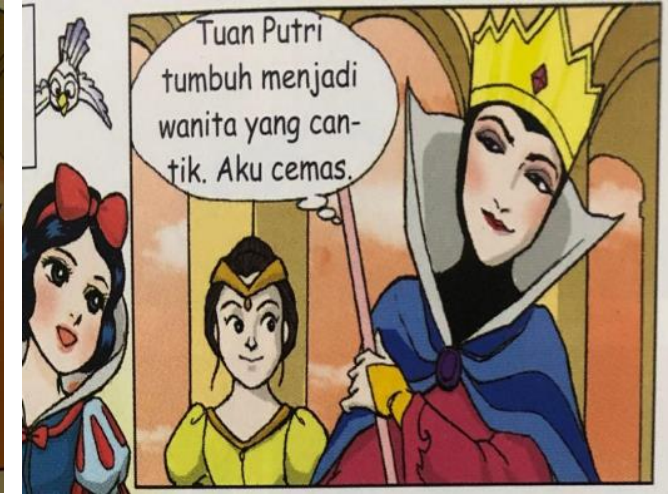

Fig. 18. The disquiet feeling of Snow White's stepmother (Indonesian Version)

Of the three stepmothers, Snow white's stepmother is appraised to be the wickedest. She caught herself attempting to kill her stepdaughter a few times. There is no worse attitude than to cause a person to die. These harm deeds are depicted in numerous scenes. The following is the most horrifying. 


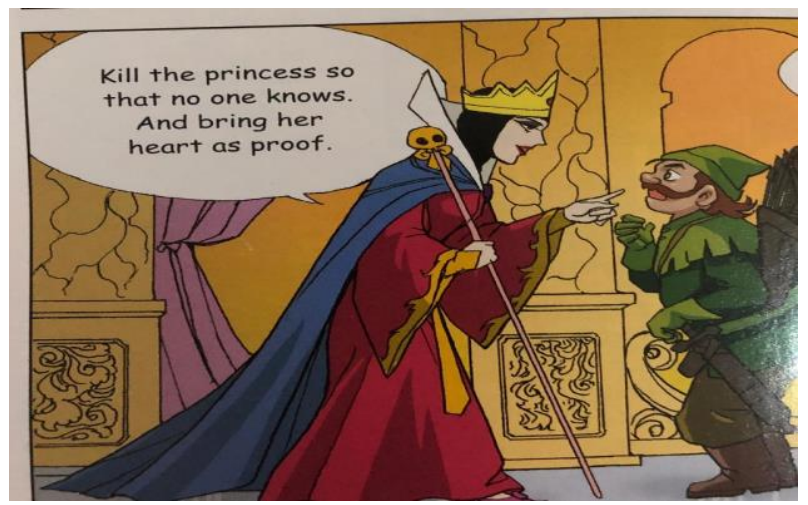

Fig. 17. The Wickedness of Snow White's Step Mother

The queen asks a huntsman to kill Snow White and to bring the queen her heart. The order is uttered in a heartless expression intensifying her vileness. The evil characterization of the stepmother is also divulged by the other characters in the comic. In Appraisal theory, this can be revealed from the analysis of Engagement which defines who is the evaluation coming from. The source of attitude of other than the author is called heterogloss and can be found in the expression uttered by the step mother's right-hand woman saying "She is as terrible and vicious as I expected.' Her bad deed is described in the words of terrible and vicious condemning the ethic aspect of personality. In Indonesian, these two words are rendered to 'menakutkan (terrifying) and kejam (equals to vicious) which conveying the same effect as the original.

\section{Discussion}

Characterization has been an important factor in the understanding of literary plays. According to Wiyatmi (in Ramadhani, 2014) [10], Characters in fiction comprise three dimensions of physiological, sociological, and psychological. In these three dimensions, there is a reflection of the emotion, behavior, and physical appearance of the character depicted in the story. The character of the wicked stepmother is well acknowledged in fairy tales. So, this evil stepmother was the first villain to be depicted in Disney's feature-length film, and since then, her terrifying nature has remained one of the key features of some fairy tale adaptations. Behrooz (2016) [11] called into questions why did this individual shape gain such popularity as the writing character, and what part specifically did the fairy tales of the Grimm brothers have to make in that? In what ways did these Brothers Grimm set out to emphasize her cruel and evil world? On her depth analysis, She found out that "one of their most striking strategies is to draw parallels between the character and actions of the stepmother, and other malevolent figures and creatures of folklore." Nanda (2014) [2] further divulged the clear link between beauty and goodness and between ugliness and evil. Beautiful Cinderella ends her life in a happy ending with a charming prince, while Snow white's stepmother perishes in her evil. I consider this worthy of further examination. The Appraisal theory is selected to be applied to scrutinize the data to see the characterization from the linguistic viewpoint.

Martin and White (2005) [5] state that "Appraisal theory provides one way of unveiling speakers and writers' ideological positions encoded in positive or negative evaluations of, and 
attitudes towards, entities." Further, White (2016) [12] states that "Appraisal is a powerful resource to understand how individuals construe realities by means of language, located in different contexts and cultures, and how discourses play a huge part in the creation of meanings in multiple social events." Wu (2013) adds that "Speakers/writers use the resources of Appraisal to negotiate their social relationships, by telling their listeners/readers how they feel about things and people, in other words, what their attitudes are."[13] This explanation strongly suggests that Appraisal is relevant to the construction of a fictional character. Khrisna (2016) affirms that Appraisal provides linguistic evidence to support the evaluation in characterization and proves to be successfully applied to explain characterization in fiction. She also found out the strong connection between Systemic Functional Language (SFL) and translation studies, particularly the application of appraisal analysis in assessing translation accuracy related to Interpersonal Metafunction. [4]

The results of this research show that among the three stepmothers, Snow White's stepmother is evaluated the evilest. The choices of words like 'kill', 'vicious', 'wicked', and the affirmation of 'I'll go to the hut and kill the princess by myself' say it all. She reaps what she saw. At the end of the story, she died a miserable death. This corroborates the statement made by Nanda (2014) revealing the clear link between beauty and goodness and between ugliness and evil.[2] Also, since fairy tales are made for kids, the authors might intend to provide moral value to the readers that "if you do bad things, bad things will happen to you, and if you do good things, good things will happen to you."

Cinderella's stepmother, however, is the luckiest. The 'worst' words used to portray her personality are only "bad" which is far from being wicked or evil as used to depict Snow White's stepmother. She does not seem to give too much trouble to her stepchildren as what the other two stepmothers do to their kids. She is not evil, she is just cruel. Her story ends in a happy ending for she expresses her regret and seeks reconciliation with her stepdaughter.

The characterization stepmother of Cinderella, Hansel and Gretel, and Snow White are not only emphasized on their cruelty but also their insecurity. This is confirmed by the linguistic evidence that presents the finding of the Attitude Affect system evaluating the emotional dimension that exceeds about the same amount with the finding of the Judgment system for measuring the personality dimension. The language used by the author shows the uneasiness felt by the stepmothers. This disquiet prompts them to do bad deeds. They find it hard to accept their new life with the presence of a kid who is not related by blood. They are on the same journey but in different shoes. It is easier for Cinderella' stepmother to mingle with her stepdaughter because she has her kids to struggle for, but a bit difficult for Hansel and Gretel's stepmom who still wishes for having her biological kid as once she told her husband "We can have a baby when we are okay." For her, the poverty and the step kids are millstones around her neck. Nevertheless, she is still alive until the end of the story and has a chance to find her own happiness.

The equivalence of characterization of stepmothers in the Indonesian and the original version also becomes the concern of this study. The result of the assessment shows the success of the translator in portraying the same character of stepmothers. Even so, there are still found several expressions that are less equal in expressive meaning. This inaccuracy is mostly due to the shift in the Graduation system. Martin and Rose (2003) define Graduations as "grammatical and lexical resources we use to "say how strongly we feel about someone or something" meaning that this important to be altered equally in the translation. [14] The utterance of "You idiot!" for instance. It expresses a strong feeling of annoyance that should be maintained in the translation. Rendering this expression to "Kamu goblok! would provide the same sense as the original than to translate it into "Kати bodoh!" (stupid). In short, readers expect to experience 
the same 'individual' as the author intends and this can only be fulfilled if the characterization is faithfully translated.

\section{Conclusion}

The Appraisal framework has discerned the other personality traits possessed by stepmothers in fairy tales, particularly the stepmother of Cinderella, Hansel and Gretel, and Snow White in WOW bilingual comics. They are notorious for their bad character, but less depicted by the magnitude of their emotions. The result of the study reveals that every bad deed they do begins with a feeling of insecurity. The profound feeling of disquiet is perceived in the story and fairly faithfully rendered in the translation. To sum up, Cinderella's stepmother is just a mom who always wants the best for her kids, Hansel and Gretel's stop mom is just a normal person who's afraid of not being able to eat, and Snow White's stepmother is just a lady who needs compliments. They might not be evil, they are just insecure.

\section{References}

[1] Blair E. Why Are Old Women Often The Face Of Evil In Fairy Tales And Folklore ? [Internet]. 2015 [cited 2020 May 6]. Available from: https://www.npr.org/2015/10/28/450657717/whyare-old-women-often-the-face-of-evil-in-fairy-tales-and-folklore

[2] Nanda S. The Portrayal of Women in the Fairy Tales. Int J Soc Sci Humanit Invent. 2014;1(4):246-50.

[3] Ouimet KR. Reba (2015) [Internet]. 2015. Available from: https://open.library.ubc.ca/cIRcle/collections/undergraduateresearch/52966/items/1.0221649

[4] Ayu D, Khrisna N, Nababan M, Riyadi S. Appraisal Analysis on The Main Character of Novel The Old Man and The Sea and Its Three Indonesian - Translated Versions Lelaki Tua dan Laut. Adv Sci Lett. 2016;22(12):4481-4.

[5] Martin J., White PRR. The Language of Evaluation: Appraisal in English. New York: PALGRAVE MACMILLAN; 2005. 278 p.

[6] Garber M. In Defense of Cinderella's Stepmother: In Kenneth Branagh's remake of the classic Disney cartoon, Cate Blanchett explores the difference between cruelty and evil. [Internet]. 2015 [cited 2020 May 7]. Available from: https://www.theatlantic.com/entertainment/archive/2015/03/in-defense-of-cinderellasstepmother/387790/

[7] KWON, Hyang S, Gongjang S. WOW! Billingual Comics: Cinderella. Jakarta: Bhuana Ilmu Populer; 2008.

[8] KWON, Hyang S, Gongjang S. WOW! Billingual Comics: Hansel and Gretel (Hansel dan Gretel). Jakarta: Bhuana Ilmu Populer; 2012.

[9] KWON, Hyang S, Gongjang S. WOW! Billingual Comics: Snow White (Putri Salju). Jakarta: Bhuana Ilmu Populer; 2008. 11 p.

[10] Ramadhani ZAR. Tingkat Apresiasi Novel Terjemahan dan Novel Asli Indonesia pada Siswa Kelas VIII MTS Negeri Bantul Kota. Universitas Negeri Yogyakarta; 2014.

[11] Behrooz A. Wicked Women: The Stepmother as a Figure of Evil in the Grimms' Fairy Tales. Retrosp J [Internet]. 2016; Available from: https://retrospectjournal.com/2016/10/26/wicked- 
women-the-stepmother-as-a-figure-of-evil-in-the-grimms-fairy-tales/

[12] Peter R. R. White. Constructing the "Stranger" in Camus' L'Étranger - Registerial and Attitudinal Variability under Translation. J Transl Stud. 2016;17(4):75-106.

[13] Wu H. Appraisal Perspective on Attitudinal Analysis of Public Service Advertising Discourse. English Lang Lit Stud [Internet]. 2013;3(1). Available from: http://dx.doi.org/10.5539/ells.v3n1p55\%0A

[14] Martin JR, Rose D. Working with Discourse. Meaning beyond the Clause. London: Continuum; 2003. 